\title{
PELATIHAN MICRO LEARNING OBJECT BERBASIS TPACK BAGI GURU-GURU SMA DI GARUT
}

\author{
Ence Surahman* ${ }^{* 1}$, Sulthoni ${ }^{1}$, Saida Ulfa ${ }^{1}$, Arafah Husna ${ }^{1}$, Hilman Ramdiana ${ }^{2}$, Zahid Zufar \\ At Thaariq ${ }^{1}$, Antoni Bagas Setiawan ${ }^{1}$, Muhammad Syifa'ul Qolbi ${ }^{1}$ \\ ${ }^{1}$ Jurusan Teknologi Pendidikan, Fakultas Ilmu Pendidikan, Universitas Negeri Malang, Indonesia \\ ${ }^{2}$ SMAN 21 Garut, Indonesia \\ ${ }^{1}$ Jalan Semarang No. 5 Malang, Jawa Timur, Indonesia \\ ${ }_{2}^{2}$ Jalan Raya Panorama Cibungur No.mor 21, Sukamulya, Talegong, Kabupaten Garut, Jawa Barat \\ *e-mail: ence.surahman.fip@um.ac.id
}

artikel masuk: 15 September 2019; artikel diterima: 6 April 2020

\begin{abstract}
The development of mobile device technology among High School (SMA) users and its equivalent has not been maximized maximally to support the achievement of effective and efficient learning goals. The purpose of this service activity is to provide training to high school / MA / SMK teachers in the form of the ability to recognize, understand and develop micro teaching materials (microlearning objects). Training activities are carried out by using a blended training model that is a combination of face-to-face training activities and online training. Face-to-face activities use lecture, discussion and online game methods, while online training is in the form of a study of training materials and independent training. The results obtained in the form of the ability of participants to understand, design and develop micro teaching materials using mobile devices they have.
\end{abstract}

Keywords: Training; microlearning object; TPACK; profesional development

\begin{abstract}
Abstrak: Perkembangan teknologi mobile device di kalangan pengguna Sekolah Menengah Atas (SMA) dan sederajat belum dioptimalkan secara maksimal untuk mendukung pencapaian tujuan pembelajaran yang efektif dan efisien. Tujuan dari kegiatan pengabdian ini yaitu memberikan pelatihan kepada para guru SMA/MA/SMK berupa kemampuan untuk mengenali, memahami dan mengembangkan bahan ajar mikro (microlearning object). Kegiatan pelatihan dilakukan dengan menggunakan model blended training yakni perpaduan antara kegiatan pelatihan secara tatap muka dan pelatihan secara online. Kegiatan tatap muka menggunakan metode ceramah, diskusi dan game online, sedangkan pelatihan online berupa kegiatan kajian bahan pelatihan dan latihan mandiri. Hasil yang diperoleh berupa kemampuan peserta dalam memahami, merancang dan mengembangkan bahan ajar mikro menggunakan perangkat mobile device yang dimilikinya.
\end{abstract}

Kata kunci: Pelatihan; microlearning object; TPACK; pengembangan profesi 


\section{PENDAHULUAN}

Talegong merupakan salah satu kecamatan di Kabupaten Garut (BPS, 2018), karena jaraknya yang jauh dari pusat ibu kota pemerintahan (146 KM) maka sering ditenggarai lambannya proses pembangunan, baik dalam konteks inprastruktur maupun pembangunan SDM. Hal itu tidak berlebihan jika dikatakan demikian, karena listrik (PLN) saja baru masuk pasca revolusi orde baru 1998 dan baru benar-benar masuk ke kampung-kampungnya di tahun 2004, kemudian jaringan telekomunikasi berbasis kabel sampai sekarang belum masuk, adapun jaringan nirkabelnya sudah masuk dari tahun 2007. Hal ini sangat wajar apabila kawasan Talegong banyak orang kota yang menjulukinya dengan daerah blankspot atau daerah yang tidak dapat terjangkau dari kucuran informasi update, walaupun setelah adanya televisi hal itu telah berubah lebih baik. Namun demikian surat kabar tercetak sampai sekarang belum ada satupun yang membuka jaringan agennnya disana, selain itu Kecamatan Talegong tidak memiliki kantor POS walaupun kode posnya terdaftar hal ini juga sering menyulitkan proses komunikasi sebelum adanya jaringan telekomunikasi seperti saat ini (Surahman, E., 2014).

Salah satu persoalan penting yang harus diperhatikan di Kecamatan Talegong adalah peningkatan mutu pendidikan. Mutu pendidikan ditentukan oleh banyak faktor, seperti kualitas pendidik dan tenaga kependidikan, kualitas kurikulum dan program pendidikan, kualitas layanan pendidikan dan pembelajaran, kualitas akses dan layanan informasi dan komunikasi, ketersediaan sarana dan prasarana pembelajaran, dan yang tidak kalah penting adalah kelengkapan sumber belajar yang memadai.

Sumber belajar merupakan segara sesuatu termasuk pesan, orang, bahan ajar, alat belajar, teknologi pembelajaran, dan lingkungan pembelajaran yang dirancang secara terencana untuk mewujudkan pembelajaran yang berkualitas (Ghafur, 1998; Nur, 2016; Rosdiana, 2007; Satrianawati, 2018; Wedi, 2017). Bahan ajar merupakan salah satu komponen penting dalam keberlangsungan proses pembelajaran yang baik. buku ajar penting karena menjadi penentu ketercapaian tujuan pembelajaran (Handayani, Setyosari, \& ..., 2017; Saleh \& Sultan, 2016; Tang, Jufri, \& Sultan, 2016). Dalam sistem pembelajaran, buku ajar memiliki peranan yang penting. Buku ajar berfungsi sebagai penanda suatu budaya literasi masyarakat khususnya masyarakat akademik. Keberadaan buku ajar merupakan bukti otentik proses penggalian ilmu berpotensi terjadi (Bendor, 2007; Gultom, 2012; Kurniawan, 2005; Mintowati, 2003).

Buku ajar merupakan sumber belajar yang berisi informasi, pembahasan, evaluasi, yang disusun secara sistematis dengan memperhatikan prinsip-prinsip pembelajaran. Buku ajar merupakan salah satu sarana keberhasilan proses pembelajaran yang berupa suatu kesatuan unit pembelajaran berisi informasi, pembahasan, evaluasi yang disusun sistematis untuk memudahkan pebelajar (Kurniawan, 2005; Mintowati, 2003). Berdasarkan definisi tersebut dapat disimpulkan bahwa yang dimaksud buku ajar adalah karya tulis yang berbentuk buku pada bidang kajian tertentu yang disusun oleh pakar pada bidang tersebut, berisi informasi, pengetahuan, dan komponen evaluasi untuk menunjang tercapainya tujuan program pembelajaran pada jenjang dan jalur tertentu.

Buku ajar bermanfaat dalam meningkatkan efektivitas dan efisiensi proses pembelajaran. Dengan tersedianya buku ajar, maka para pebelajar dan pengajar dapat meminimalisir waktu dalam pencarian sumber belajar yang dibutuhkan. Selain itu buku ajar dapat menjadi pemandu bagi pebelajar dan pengajar untuk mengukur progres belajarnya secara lebih baik.

Buku ajar yang baik idealnya memenuhi beberapa unsur berikut: (1) buku ajar merupakan buku pelajaran yang ditunjukan bagi pebelajar pada jenjang tertentu. (2) buku ajar selalu berkaitan dengan mata pelajaran tertentu. (3) Buku ajar merupakan buku standar. (4) buku ajar ditulis untuk 
tujuan instruksional tertentu. (5) buku ajar ditulis untuk menunjang suatu program pembelajaran tertentu (Zaenal, 2009).

Buku ajar merupakan salah satu sumber belajar yang paling banyak digunakan di semua sekolah yang berada di Kecamatan Talegong. Hal itu disebabkan layanan akses informasi yang belum semudah di sekolah perkotaan. Buku ajar yang ada pun hanya yang terkait mata pelajaran yang diajarkan. Sedangkan buku-buku umum tidak tersedia. Hal itu sesuai dengan hasil wawancara dengan perwakilan guru dari tiga sekolah jenjang menengah atas yang ada di sana.

Berdasarkan data hasil survei yang dilakukan sebelum kegiatan dilaksanakan dapat dijelaskan bahwa total jumlah guru dari ketiga sekolah tersebut sebanyak 42 orang dengan total jumlah siswa sebanyak 661. Total guru dan siswa terbanyak ada di SMAN 21 Garut. Satu-satunya SMA negeri di Kecamatan Talegong. Sekolah tersebut berdiri tahun 2002. Sementara itu untuk dua sekolah berikutnya karena masih baru sehingga data kuantitatifnya juga relatif masih sangat kurang. Hal itu tidak lepas dari statusnya sebagai sekolah swasta milik yayasan dan lokasi sekolah yang berada jauh dari ibu kota kecamatan.

Berdasarkan analisis situasi pada pendahuluan di atas dapat digaris bawahi bahwa masalah yang mendasar yang perlu segera diatasi adalah guru dan siswa di SMA/SMK Kecamatan Talegong Garut mengalami kesulitan dalam memperoleh bahan ajar alternatif yang valid selain buku ajar yang disediakan pemerintah. Sehingga para guru perlu diberikan pelatihan dalam bentuk pengembangan dan pemanfaatan bahan ajar alternatif yang kami beri nama Micro Learning Object (MLO) terintegrasi Cloud Learning Resources (CLR) dengan pendekatan TPACK.

Secara khusus garis besar masalah yang dihadapi mitra dapat dijabarkan sebagai berikut: (1) sekolah memiliki keterbatasan fasilitas dan layanan serta kelengkapan koleksi perpustakaan sebagai sumber belajar siswa; (2) sekolah memiliki keterbatasan fasilitas informasi online melalui internet yang dapat dimanfaatkan oleh siswa untuk mencari dan menemukan sumber belajar tambahan secara daring (online); (3) 94,9\% siswa mengaku membutuhkan bahan ajar tambahan selain buku ajar untuk menunjang kebutuhan materi pelajaran baik yang dapat dipelajari di sekolah maupun di rumah; (4) $74,6 \%$ siswa mengaku mengalami kesulitan dalam memahami isi buku ajar secara mandiri sehingga diperlukan bahan ajar tambahan dengan menggunakan bahasa guru agar lebih mudah dipahami; (5) akses siswa ke toko buku yang menyediakan buku pelajaran sangat terbatas (jaraknya puluhan KM); (6) guru yang memiliki kemampuan mengembangkan bahan ajar mandiri masih sedikit dan perlu mendapatkan pelatihan; (7) pemahaman dan pengalaman guru tentang Micro Learning Object (MLO) masih minim dan mereka membutuhkan pelatihan tentang hal itu; (8) pemahaman dan pengalaman guru dalam memanfaatkan fitur Cloud Learning Resources masih minim dan mereka membutuhkan pelatihan tentang hal itu; (9) $88,1 \%$ siswa mengaku memiliki sosial media dan aktif menggunakannya, bahkan 47,5\% mengaku menggunakan sosial media selama 1-2 jam/hari. Dengan demikian perlu ada upaya pemanfaatan sosial media yang menunjang kebutuhan pembelajaran melalui penyediaan bahan ajar tambahan.

Pelatihan Pengembangan dan pemanfaatan Micro Learning Object (MLO) terintegrasi Cloud Learning Resources (CLR) dengan Pendekatan Technological Pedagogical Content Knowledge (TPACK) Bagi Guru-Guru SMA/SMK Di Talegong Garut merupakan serangkaian kegiatan mulai dari tahap analisis kebutuhan, analisi program, perancangan program pelatihan, pelaksanaan, pengawasan dan evaluasi program pelatihan yang bertujuan untuk meningkatkan pemahaman dan keterampilan guru untuk menjadi penyedia bahan ajar mikro sebagai upaya untuk meningkatkan kualitas pembelajaran siswa.

Micro Learning Obect (MLO) merupakan istilah yang baru berkembang dalam dunia media pembelajaran era digital dewasa ini (Li, Liu, Han, \& Zhang, 2011; Stephansen \& Couldry, 2014). 
Konsep MLO merupakan gambungan dari termonologi mikro learning (pembelajaran mikro) dengan learning object (bahan ajar). MLO memiliki karakteristik sederhana, spesifik, menarik, mudah disalurkan, mudah digunakan dan terintegrasi dengan internet atau sosial media yang sudah digrandungi oleh para siswa.

Microlearning merupakan produk perubahan paradigma epistimologi ilmu dan pengetahuan umat manusia (Li et al., 2011; Mercurio, Torre, \& Torsani, 2011; Sánchez-Alonso, Sicilia, GarcíaBarriocanal, \& Armas, 2006; Stephansen \& Couldry, 2014). Microlearning menginginkan proses konstruksi ilmu pengetahuan dan pengalaman pada diri pebelajar dapat dilakukan secara singkat, padat, jelas, sederhana, dan memudahkan. Materi dalam e-learning disajikan berupa bagian-bagian. Sebagaimana hasil penelitian (Giurgiu, 2017) menunjukkan bahwa konten belajar yang berupa irisan-irisan materi terbukti membatu pebelajar untuk mengingat materi lebih baik.

Microlearning lahir dari munculnya terminologi microcontent. Microcontent merupakan informasi digital yang sedikit (Job \& Ogalo, 2012). Microlearning mendukung proses dokumentasi pengetahuan. Microlearning telah secar masif mempengaruhi pola belajar era digital.

Pembelajaran mikro berkaitan dengan unit pembelajaran yang relatif kecil dan kegiatan pembelajaran jangka pendek. Istilah ini digunakan dalam e-learning dan bidang terkait dalam arti proses pembelajaran di lingkungan yang dimediasi (Yasung Park \& Kim, 2018; Sánchez-Alonso et al., 2006). Pembelajaran mikro adalah pendekatan holistik untuk pembelajaran dan pendidikan berbasis keterampilan yang berhubungan dengan unit pembelajaran yang relatif kecil.

Ini melibatkan strategi jangka pendek yang berfokus khusus dirancang untuk pemahaman/ pembelajaran/ pendidikan berbasis keterampilan. Pembelajaran mikro mengacu pada perspektif mikro pembelajaran, pendidikan, pelatihan dan pengembangan keterampilan. Pendekatan yang diikuti untuk penilaian pembelajaran mikro bersifat multidimensi \& holistik dan berdasarkan kebutuhan dalam kasus-kasus tertentu.

Pembelajaran mikro telah dianggap sebagai pendekatan pedagogis spesifik yang berfokus pada penggunaan microcontent sebagai akun khusus, kecil dan subjektif dari konsep "sumber belajar" (Sánchez-Alonso et al., 2006). Hal ini menunjukkan bahwa paradigma objek belajar berupa metadata.

(Sun, Cui, Chen, Guo, \& Shen, 2015) pernah melakukan penelitian tentang implementasi sistem awan untuk Microlearning bergerak dalam bentuk Massive Open Online Courses (MOOC). Menurutnya Microlearning merupakan strategi penyediaan konten belajar dalam konteks pembelajaran online yang dalam dikembangkan secara cerdas dengan kemampuannya memahami perilaku dan mengenali fitur sumber belajar yang digunakan.

(Buchem \& Hamelmann, 2010) berargumentasi bahwa microlearning dipandang sebagai sebuah strategi dalam pengembangan profesi berkelanjutan. Hal itu didasarkan pada pandangan bahwa microlearning dalam komunitas online sebagai pendekatan pembelajaran yang dipicu oleh pola penggunaan media saat ini dan didukung oleh teknologi baru, seperti Web 2.0 dan perangkat lunak sosial.

Cloud Learning Resources (CLR) merupakan istilah untuk fitur penyedia sumber belajar online yang tersimpan dalam komputasi awan (cyber world) (Bora \& Ahmed, 2013; Chen, Lin, \& Zhang, 2011; Ding, Xiong, \& Liu, 2015). CLR merupakan inovasi sumber belajar era digital khusunya sejak kemunculan teknologi komputasi awan (cloud computing). Keunggulan CLR adalah efisiensi ukuran penyimpanan dokumen karena tidak membutuhkan ukuran penyimpanan pada peralatan komputer/laptop/smartphone. Di samping itu kemudahan untuk diakses dari mana saja, kapan saja, oleh siapa saja yang terkoneksi. Hal tersebut memudakan pengguna untuk memanfaatkannya. 
Technological Pedagogical Content Knowledge (TPACK) merupakan sebuah kerangka kerja (framework) model pembelajaran baru yang menggabungkan tiga aspek di dalamnya yaitu pedagogi (ilmu mendidik), teknologi (teknik pendidikan) dan konten (isi/kajian/materi pengetahuan dalam pendidikan) (Hartati, 2018; Hidayati, Setyosari, \& ..., 2019). TPACK muncul sejalan dengan perkembangan teknologi dalam bidang pendidikan dan pembelajaran.

Setelah mengikuti kegiatan pelatihan pengembangan dan pemanfaatan Micro Learning Object (MLO) terintegrasi Cloud Learning Resources (CLR) dengan Pendekatan Technological Pedagogical Content Knowledge (TPACK) para peserta diharapkan memiliki pengetahuan dan keterampilan serta sikap yang baik dalam mengembangkan dan memanfaatkan Micro Learning Object (MLO) terintegrasi Cloud Learning Resources (CLR) dengan Pendekatan Technological Pedagogical Content Knowledge (TPACK) dalam kegiatan pembelajaran sehari-hari sesuai dengan mata pelajaran yang diampunya.

Pada akhir kegiatan pelatihan para peserta diharapkan mampu: (1) menjelaskan konsep dasar Micro Learning Object (MLO) secara teoritis dan praktis dalam kegiatan pembelajaran; (2) menjelaskan konsep dasar Cloud Learning Resources (CLR) secara teoritis dan praktis implementasinya dalam kegiatan pembelajaran; (3) menjelaskan konsep dasar Technological Pedagogical Content Knowledge (TPACK) kaitannya dengan pengembangan Micro Learning Object (MLO); (4) membuat desain Micro Learning Object (MLO) pada satu pokok bahasan materi pelajaran yang diampunya; (5) memanfaatkan Micro Learning Object (MLO) terintegrasi Cloud Learning Resources (CLR) dengan pendekatan TPACK; (6) mengukur respon dan hasil belajar siswa terhadap pemanfaatan Micro Learning Object (MLO) terintegrasi Cloud Learning Resources (CLR) dengan pendekatan TPACK.

\section{METODE}

Tahap kegiatan yang akan dilakukan untuk mencapai tujuan dari kegiatan pengabdian kepada masyarakat ini adalah sebagai berikut: (1) pelaksana abdimas melakukan analisis kebutuhan lapangan dengan cara wawancara online tidak terstruktur kepada para guru dari lembaga mitra sasaran; (2) pelaksana abdimas mendalami hasil analisis kebutuhan yang diperoleh dengan cara menyebar kuisioner online tentang ketersediaan layanan dan fasilitas sumber belajar di lembaga sasaran. Diperoleh data sebanyak 59 responden yang memberikan tanggapan atau sebanyak $(8,9 \%)$ dari seluruh siswa pada lembaga sasaran; (3) pelaksana abdimas menyusun dokumen kurikulum program pelatihan yang sesuai dengan kebutuhan mitra sasaran program kemudian ditawarkan kepada calon mitra dan disetujui; (4) pelaksana abdimas mengembangkan bahan ajar (modul) pelatihan, bahan tayang materi pelatihan, serta online courses pada http://elearning.um.ac.id/ untuk pendampingan online setelah kegiatan pelatihan di lapangan; (5) pelaksanakan kegiatan pelatihan dengan model blended training yakni pelatihan yang dikemas dengan kegiatan tatap muka dan kegiatan pembelajaran dalam jaringan pada http://elearning.um.ac.id/; (6) pendampingan teknis dalam pembuatan rancangan Micro Learning Object (MLO) terintegrasi Cloud Learning Resources (CLR) dengan Pendekatan Technological Pedagogical Content Knowledge (TPACK); (7) pendampingan teknis dalam pengembangan Micro Learning Object (MLO) terintegrasi Cloud Learning Resources (CLR) dengan Pendekatan Technological Pedagogical Content Knowledge (TPACK); (8) pendampingan teknis dalam pemanfaatan Micro Learning Object (MLO) terintegrasi Cloud Learning Resources (CLR) dengan Pendekatan Technological Pedagogical Content Knowledge (TPACK); (9) pendampingan teknis dalam pengukuran hasil dan umpan balik terhadap Micro Learning Object (MLO) terintegrasi Cloud Learning Resources (CLR) dengan Pendekatan Technological Pedagogical Content 
Knowledge (TPACK); (10) penyusunan laporan dan luaran hasil kegiatan abdimas sesuai dengan rencana awal. Adapun agenda teknis perencanaan, pelaksanaan dan pelaporan abdimas dapat ditampilkan dalam gambar 1.

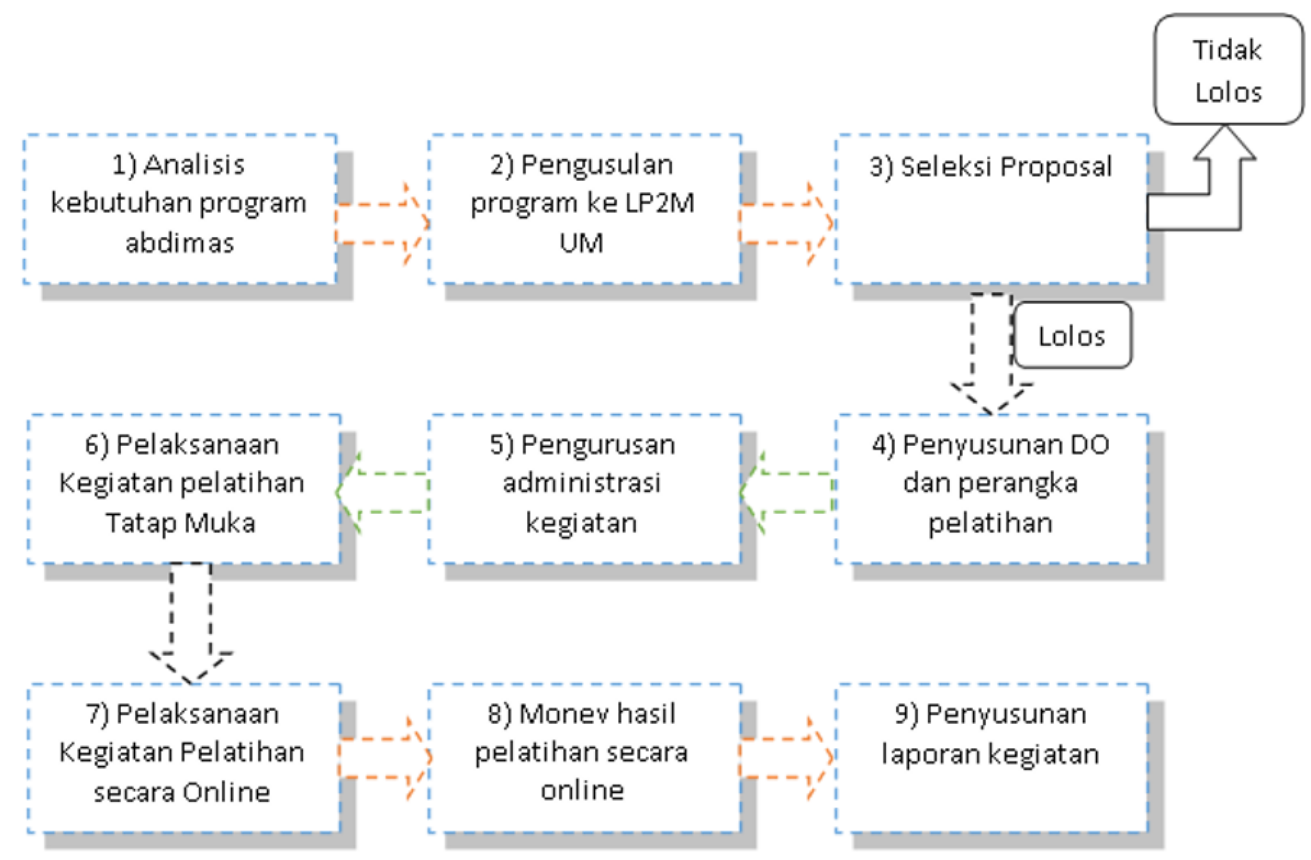

Gambar 1. Agenda teknis perencanaan, pelaksanaan dan pelaporan abdimas

Adapun metode pelatihan yang digunakan dalam kegiatan pelatihan meliputi: (1) brainstorming awal tentang konsep-konsep dasar materi yang dilatihkan yakni Micro Learning Object (MLO), Cloud Learning Resources (CLR) dan Technological Pedagogical Content Knowledge (TPACK); (2) ceramah dan tanya jawab tentang pengantar Micro Learning Object (MLO) terintegrasi Cloud Learning Resources (CLR) dengan Pendekatan Technological Pedagogical Content Knowledge (TPACK); (3) workshop pembuatan rancangan Micro Learning Object (MLO) pada satu topik materi pelajaran; (4) workshop pengembangan Micro Learning Object (MLO) pada satu topik materi pelajaran; (5) workshop pengembangan Cloud Learning Resources (CLR) pada aplikasi Google Drive masing-masing akun peserta; (6) simulasi pemanfaatan Micro Learning Object (MLO) terintegrasi Cloud Learning Resources (CLR) antar sesama peserta pelatihan; (7) penyusunan rancangan pengukuran respon siswa terhadap pemanfaatan Micro Learning Object (MLO) terintegrasi Cloud Learning Resources (CLR); (8) pengumpulan produk pelatihan Micro Learning Object (MLO) terintegrasi Cloud Learning Resources (CLR) untuk validasi isi dan validasi media; (9) diskusi pelaksanaan pelatihan dan rencana tindak lanjut pelatihan dalam bentuk pelatihan online pada http://e-learning.um.ac.id/. Tampilan online training of micro learning object terlihat sebagaimana pada gambar 2.

Adapun Evaluasi dalam kegiatan pengabdian kepada masyarakat ini dilakukan terhadap proses dan hasil pelatihan dengan rincian sebagai berikut: (1) evaluasi proses pelatihan meliputi: a) keaktifan peserta, sebagai indikator dan tolok ukurnya yaitu: kehadiran dilihat dari presensi pada setiap materi pelatihan, aktivitas dilihat dari keterlibatan peserta dalam diskusi, tanya jawab, latihan individu, antusiasme dalam praktik dan simulasi materi pelatihan, b) keterampilan peserta, sebagai indikator dan tolok ukurnya yaitu: keterampilan dalam membuat rancangan Micro Learning Object (MLO), keterampilan dalam mengembangan produk Micro Learning Object (MLO), keterampilan dalam mengembangkan Cloud Learning Resources (CLR), keterampilan 
dalam mensimulasikan pemanfaatan produk Micro Learning Object (MLO) terintegrasi Cloud Learning Resources (CLR); (2) evaluasi hasil pelatihan meliputi: a) peningkatan pemahaman peserta terhadap materi pengantar Micro Learning Object (MLO) terintegrasi Cloud Learning Resources (CLR) dengan pendekatan TPACK, b) produk Micro Learning Object (MLO) terintegrasi Cloud Learning Resources (CLR) yang dihasilkan oleh masing-masing peserta pelatihan minimal satu produk pada satu pokok bahasan materi pelajaran.

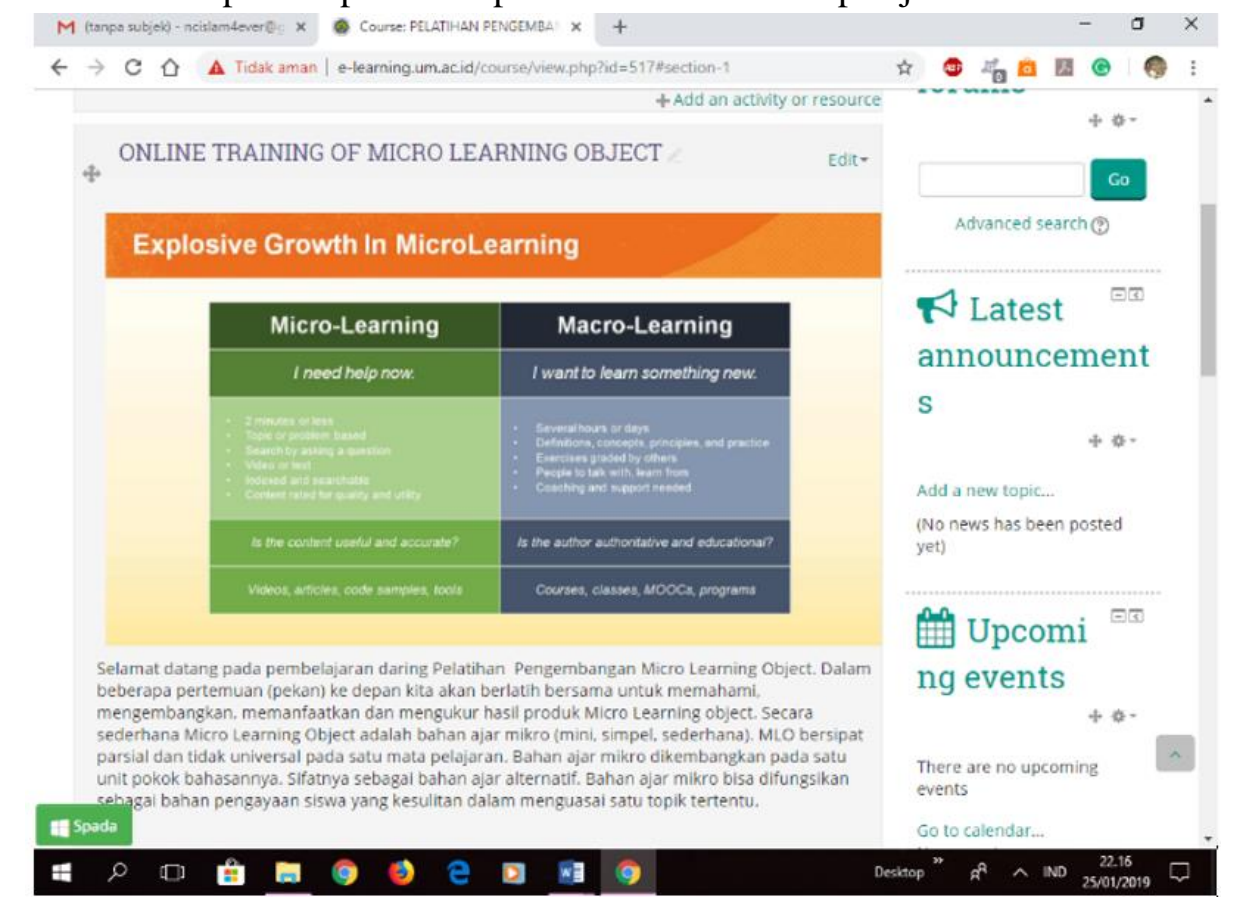

Gambar 2. Tampilan Online Training Of Micro Learning Object

\section{HASIL DAN PEMBAHASAN}

Secara umum kegiatan berjalan lancar sesuai dengan yang direncanakan, namun ada perubahan waktu pelaksanaan menyesuaikan dengan kesediaan para peserta dan fasilitator dari lembaga mitra. Awalnya direncanakan dilaksanakan Sabtu, 8 Juni 2019 (setelah lebaran), namun berdasarkan hasil pertimbangan dan diskusi dengan pihak mitra, maka acara dimajukan ke Sabtu, 1 Juni 2019. Dengan pertimbangan para peserta dapat hadir dan tidak terganggu oleh kegiatan liburan dan kegiatan keluarganya masing-masing.

Jumlah peserta yang hadir mengalami perubahan dari yang direncanakan, awalnya direncanakan yang hadir sebanyak 31 orang, namun yang benar-benar hadir sebanyak 24 orang peserta. Namun ditambah dengan pemateri, dan panitia pelaksana jumlahnya sebanyak 31 orang.

Secara umum proses pembelajaran dalam pelatihan dimulai dengan kegiatan pembukaan, dan penyampaian maksud dan tujuan dari pelaksanana program pengabdian pada masyarakat. Selanjutnya sambutan penerimaan dari pihak lembaga mitra. Selanjutnya memasuki materi pertama tentang pengembangan profesionalisme guru. Dilanjutkan dengan tanya jawab. Lalu masuk pada materi tentang micro learning object, yang dimulai dari kegiatan pre test, pematerian, diskusi tanya jawab, post test, dan lanjutan pelatihan dalam sistem online yang dipantau dari jarak jauh. Setelah selesai pematerian, ada penutupan dari perwakilan mitra yang diwakili oleh wakil Kepala Sekolah Bidang Kurikulum.

Berdasarkan data hasil pre test dan post test dapat dijelaskan bahwa semua peserta mengalami peningkatan signifikan. Walaupun materi pelatihan dipandang baru, namun beberapa 
peserta dapat mengikuti dengan baik materinya yang dibuktikan dengan hasil post test yang mengalami peningkatan.

Berdasarkan gambar 3 dapat dijelaskan bahwa terdapat peningkatan hasil belajar para peserta antara sebelum dan sesudah mengikuti kegiatan pelatihan dengan peningkatan sebesar 27. Hal itu dapat dihitung dari rata-rata skor post test dikurangi skor pre test. 77,9-50.9=27. Data peningkatan tersebut membuktikan bahwa para peserta semakin memahami materi tentang micro learning objek yang diajarkan dalam materi pelatihan.

Berdasarkan data pada gambar 4, dapat dilihat bahwa sebaran usia para peserta pelatihan dominan diantara 20-30 tahun dengan prosentase sebsar 54\%. Selanjutnya usia 30-40 tahun sebanyak 33\%. Dan $13 \%$ peserta berusia diatas 40 tahun. Usia para peserta peserta termasuk kategori usia produktif dalam bekerja. Dengan demikian, harapannya para peserta pelatihan mau memanfaatkan ilmu hasil pelatihan dalam kegiatan pembelajarannya disekolah masing-masing.



Gambar 3. Data rata-rata peningkatan skor pre test dan post test

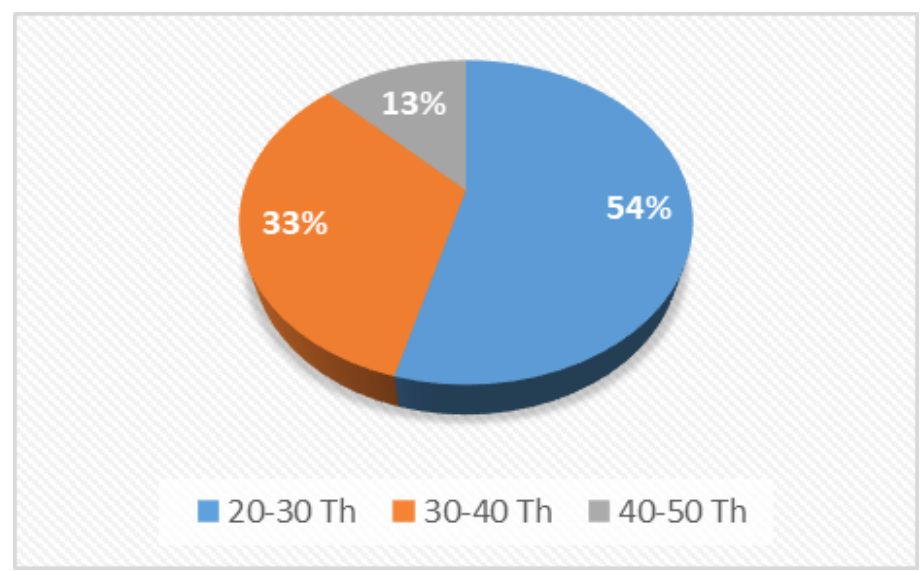

\section{Gambar 4. Sebaran usia para peserta}






\section{Gambar 5. Gender pada peserta}
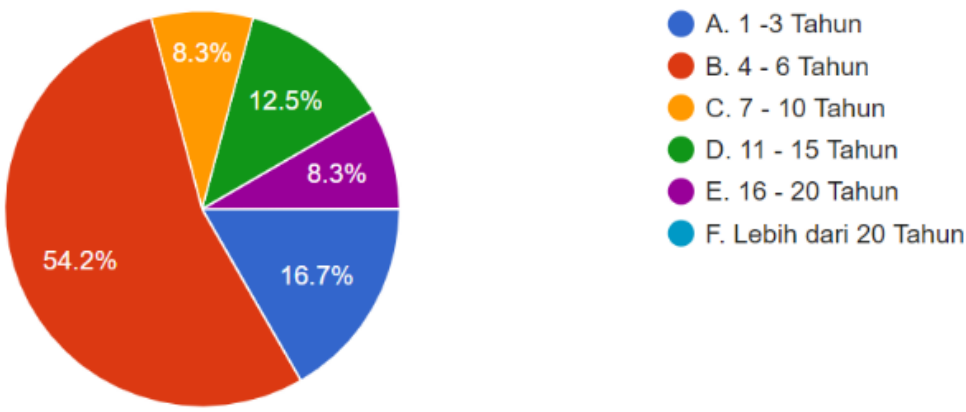

\section{Gambar 6. Pengalaman Mengajar}

Berdasarkan data pada gambar 5 dapat dijelaskan bahwa $75 \%$ para peserta berasal dari jenis kelamin laki-laki dan 25\% berasal dari jenis kelamin perempuan. Data pada gambar 5 di atas sejalan dengan data pengalaman mengajar pada gambar 6 . Berdasarkan hasil survei $54,2 \%$ peserta memiliki rata-rata usia mengajar antara 4-6 tahun. Sedangkan $16,7 \%$ memiliki usia mengajar kurang dari 3 tahun. 8,3\% peserta memiliki masa mengajar 7-10 dan 1620 tahun. Dan sebesar $12,5 \%$ peserta mengaku memiliki pengalaman mengajar antara 11-15 tahun.

Selanjutnya kami sajikan data hasil analisis tentang kompetensi para peserta pelatihandari perspektif TPACK. Berdasarkan hasil survei yang kami lakukan berikut kami sajikan data hasilnya pada beberapa indikator TPACK yaitu: (1) indikator kemampuan mengetahui bagaimana mengatasi masalah teknis yang terkait dengan perangkat keras komputer atau perangkat lunak, berdasarkan grafik pada gambar 7 dapat dijelaskan bahwa 45,8\% peserta mengaku setuju bahwa dirinya memiliki kemampuan untuk mengatasi masalah teknis dalam komputer. Hal yang sama untuk yang tidak memilikinya sebesar $45,8 \%$. Dan hanya $8,3 \%$ yang mengaku sangat setuju, artinya memiliki kemampuan untuk mengatasi masalah teknis dalam pengoperasian komputer. Hal itu disebabkan yang bersangkutan adalah guru pengampu mata pelajaran TIK; (2) indikator tentang kepemilikan pengetahuan yang cukup tentang subjek pegetahuan inti, indikator ini menjelaskan tentang kompetensi profesionalisme guru 29,2\% mengaku sangat setuju dirinya memiliki kompetensi inti dari mata pelajaran yang diampunya 62,5\% mengaku setuju (Gambar 8). Dan hanya $8,3 \%$ yang tidak setuju bahwa dirinya telah merasa memiliki kemampuan yang cukup. Hal itu disebabkan yang bersangkutan mengajar mata pelajaran yang berbeda dengan bidang keilmuan yang dipelajarinya waktu kuliah; (3) indikator pengetahuan dalam menilai kinerja siswa 
di kelas, berdasarkan data pada gambar 9 tentang kemampuan menilai siswa, dapat disimpulkan bahwa 29,2 peserta mengaku sangat setuju dirinya mampu menilai kemampuan siswa, dan 70,8\% mengaku setuju bahwa dirinya memiliki kemampuan dalam menilai kinerja siswa. Hal itu mengindikasikan bahwa bagi para guru proses menilai bukan merupakan hal yang sulit; (4) indikator kemampuan memilih pendekatan pengajaran yang efektif untuk memandu pemikiran dan pembelajaran siswa dalam bidang studi, berdasarkan informasi pada gambar 10, dapat disimpulkan bahwa $29,2 \%$ peserta mengaju sangat setuju dan $62,5 \%$ mengaku setuju bahwa dirinya dapat memilih pendekatan pembelajaran yang tepat untuk materi yang diajarkannya.

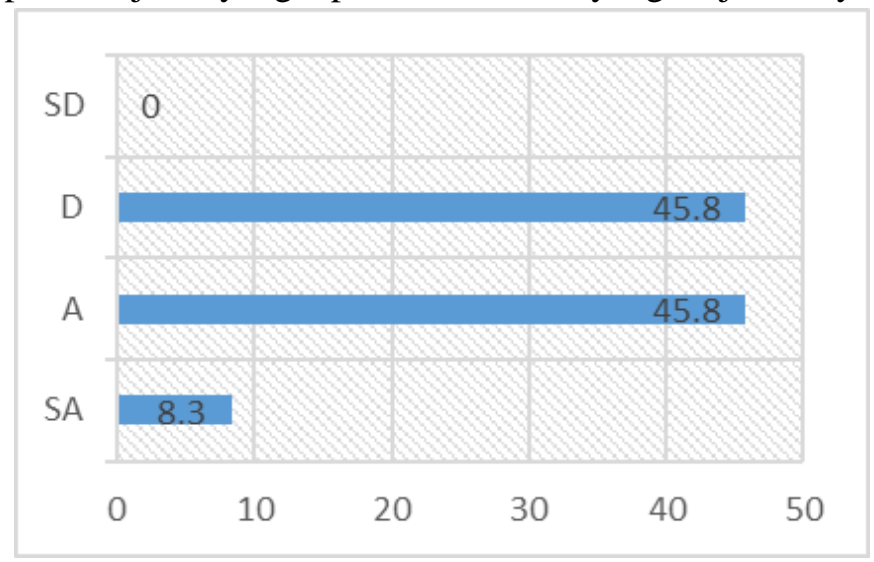

\section{Gambar 7. Pengetahuan mengatasi masalah teknis}



Gambar 8. Pengetahuan subjek inti

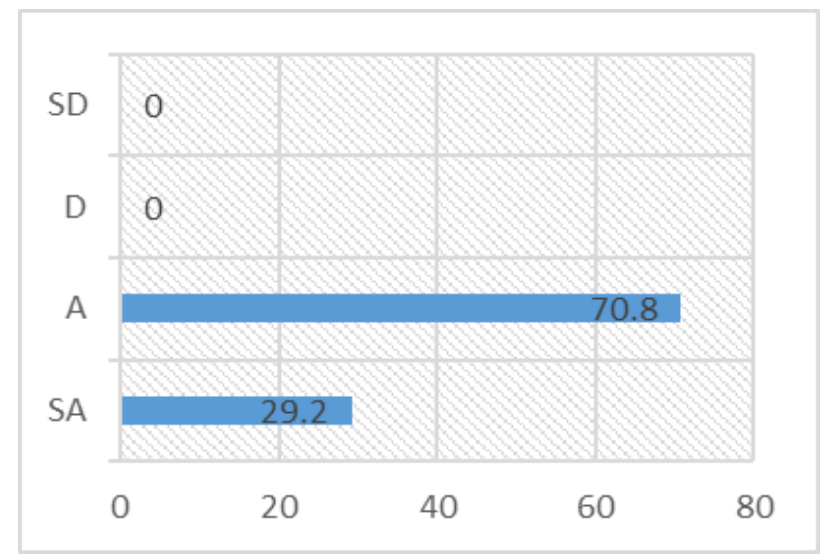

Gambar 9. Kemampuan menilai siswa 


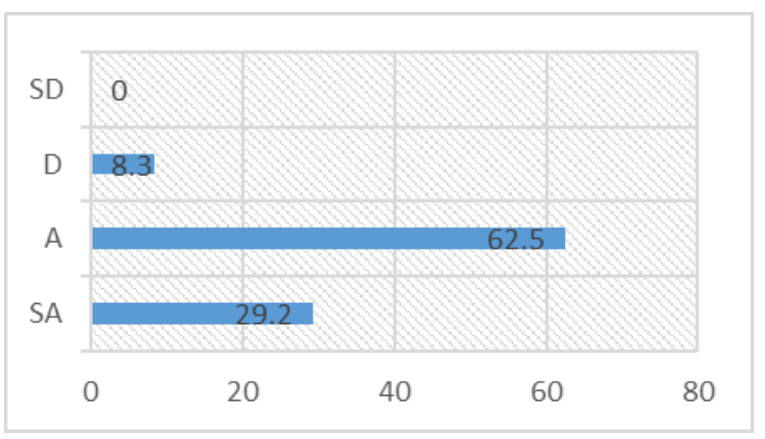

Gambar 10. Menentukan pendekatan pembelajaran yang efektif

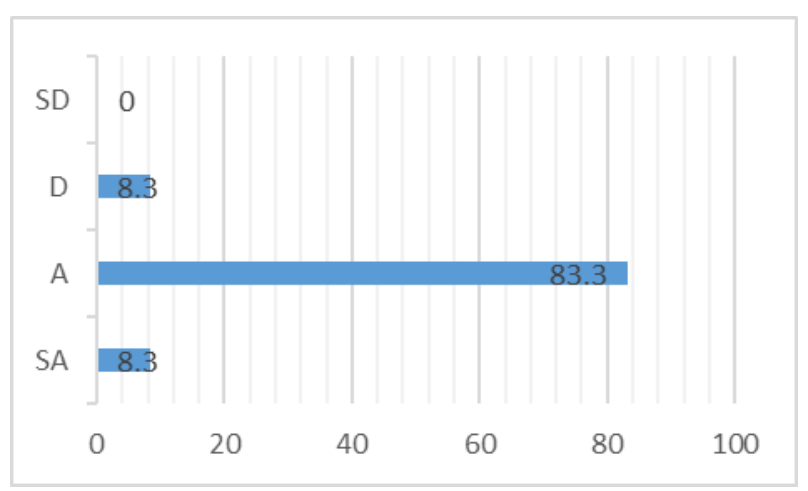

\section{Gambar 11. Kemampuan TPACK dalam pembelajaran}

Sementara itu ada $8,3 \%$ peserta yang mengaku belum dapat menentukan dengan mudah pendekatan pembelajaran yang harus digunakannya. Hal itu bisa terjadi pada guru yang belum memiliki pengalaman mengajar yang lama; (5) indiaktor kemampuan mengajarkan pelajaran yang tepat menggabungkan subjek bidang studi, teknologi, dan pendekatan pengajaran, gambar 11 menjelaskan informasi bahwa $8,3 \%$ peserta yang mengaku sangat setuju bahwa dirinya dapat menggabungkan teknologi, pedagogi, pengetahuan dalam pembelajaran yang dilakukannya. Sedangkan 83,3 mengaku setuju dapat melakukan itu. Dan hanya 8,3\% yang mengaku tidak bisa mengajar menggunakan model TPACK. Hal itu bisa terjadi pada kalangan guru yang masuk kategori baby boomer yakni guru yang belum familiar dengan pemanfaatan TIK dalam pembelajaran.

Berdasarkan data dan informasi yang telah dijelaskan sebelumnya, dapat disimpulkan bahwa para peserta tertarik dengan pelatihan yang dilakukan. Para peserta menyukai game online dalam pembelajaran. Para pesera mayoritas mengaku bahwa dirinya mudah menetukan pendekatan pembelajaran, bisa menggunakan komputer dan media dalam pembelajaran. Serta tertarik dengan model-model pembelajaran yang sesuai dengan corak pembelajaran abad 21.

Pelatihan dengan menggunakan model blended training terbukti mampu meningkatkatkan hasil belajar para peserta. Hal itu dapat dilihat dari kenaikan rata-rata skor sebelum dan sesudah pembelajaran dilaksanakan (Locatis et al., 2006; Lotrecchiano, McDonald, Lyons, Long, \& Zajicek-Farber, 2013). Para peserta merasa lebih nyaman berinteraksi dalam belajar menggunakan bantuan teknologi (Mouzakis, 2008).

Para peserta kebanyakan dari kalangan pengajar muda yang rata-rata memiliki pengalaman antara 4-6 tahun. Dengan demikian kebanyakan tidak mengalami kesulitan dalam menggunakan perangkat teknologi informasi dan komunikasi untuk kepentingan pembelajaran (Hsieh, Huang, \& Wu, 2017; Hu, Griffin, \& Bertuleit, 2016; Yeonjeong Park, 2011). Hal tersebut sejalan dengan hasil kuisioner TPACK yang diisi oleh para peserta. Rata-rata para peserta sudah memiliki 
kemampuan memadukan komponen teknologi dan pedagogi dalam pembelajarnanya (Baran, Canbazoglu Bilici, Albayrak Sari, \& Tondeur, 2019; Chai, Koh, \& Tsai, 2010; Hartati, 2018; Herring, Koehler, \& Mishra, 2016; Koh, Chai, \& Lim, 2017; Pamuk, Ergun, Cakir, Yilmaz, \& Ayas, 2015).

Pembelajaran secara blended para era digital dapat dirancang secara terintegrasi. Dalam artian semua komponen pembelajaran dapat dikemas secara online menggunakan sarana pembelajaran daring (Surahman, 2019). Hal itu penting untuk dilakukan dalam rangka membiasakan budaya kolaborasi akademik dari berbagai belahan dunia.

\section{SIMPULAN}

Berdasarkan data di atas dapat disimpulkan beberapa hal yaitu; (1) para peserta antusias mengikuti materi dari awal hingga akhir; (2) peserta tertarik untuk mendalami materi micro learning object; (3) para peserta dapat mengikuti pembelajaran pelatihan secara blended antara kegiatan tatap muka dengan pembelajaran online; (4) peserta tertarik untuk mencoba mengembangkan dalam pembelajarannya; (5) para peserta berharap ada program pelatihan lanjutan pada tema-tema seputar peningkatan kemampuan meneliti dan menulis karya ilmiah. Berdasarkan hasil evaluasi hasil pelatihan dan berdasarkan hasil isian kuisioner yang dilakukan oleh para peserta diperoleh beberapa informasi untuk perbaikan kedepannya. Rekomendasi yang dapat disampaikan ialah para peserta dapat mencoba secara langsung hasil yang diperoleh dalam pelatihan melalui pengembangan konten pembelajaran mikro pada mata pelajaran yang diampunya masing-masing.

\section{DAFTAR RUJUKAN}

Baran, E., Canbazoglu Bilici, S., Albayrak Sari, A., \& Tondeur, J. (2019). Investigating the impact of teacher education strategies on preservice teachers' TPACK. British Journal of Educational Technology, 50(1), 357-370.

Bendor, J. (2007). Self editing and Revisions: Bahan Pelatihan Penulisan Artikel Ilmiah Internasional. DP2M: Jakarta.

Bora, U. J., \& Ahmed, M. (2013). E-learning using cloud computing. International Journal of Science and Modern Engineering, 1(2), 9-12.

BPS. (2018). Kecamatan Talegong Dalam Angka. Garut.

Buchem, I., \& Hamelmann, H. (2010). Microlearning: a strategy for ongoing professional development. ELearning Papers, 21(7), 1-15.

Chai, C. S., Koh, J. H. L., \& Tsai, C.-C. (2010). Facilitating preservice teachers' development of technological, pedagogical, and content knowledge (TPACK). Journal of Educational Technology \& Society, 13(4), 63-73.

Chen, S., Lin, M., \& Zhang, H. (2011). Research of mobile learning system based on cloud computing. Proceeding of the International Conference on E-Education, Entertainment and e-Management, 121-123. IEEE.

Ding, J., Xiong, C., \& Liu, H. (2015). Construction of a digital learning environment based on cloud computing. British Journal of Educational Technology, 46(6), 1367-1377.

Ghafur, A. (1998). Sumber Belajar. Yogyakarta.

Giurgiu, L. (2017). Microlearning an evolving elearning trend. Scientific Bulletin, 22(1), 18-23.

Gultom, S. (2012). Pedoman Penulisan Buku Ajar Peningkatan Kompetensi Pendidik Pendidikan Nonformal. Jakarta. Kemendikbud.

Handayani, A., Setyosari, P., \& ... (2017). Pengembangan Bahan Ajar Biologi Berbasis Multimedia Untuk Siswa Kelas VIII SMP Islam Yakin Tutur Kabupaten Pasuruan. 
Edcomtech Jurnal Kajian ... Retrieved from http://journal2.um.ac.id/index.php/ edcomtech/article/view/2073

Hartati, T. (2018). Techonological Pedagogical Content Knowledge (Tpack) Dalam Rangka Peningkatan Kualitas Pembelajaran Mahasiswa PPG SD .... EDUTECH. Retrieved from http://ejournal.upi.edu/index.php/edutech/article/view/15092

Herring, M. C., Koehler, M. J., \& Mishra, P. (2016). Handbook of technological pedagogical content knowledge (TPACK) for educators. Routledge.

Hidayati, N., Setyosari, P., \& ... (2019). Kompetensi Technological Pedagogical Content Knowledge (Tpack) Guru Soshum Setingkat SMA. Jurnal Kajian Teknologi .... Retrieved from http://journal2.um.ac.id/index.php/jktp/article/view/6720

Hsieh, J. S. C., Huang, Y.-M., \& Wu, W.-C. V. (2017). Technological acceptance of LINE in flipped EFL oral training. Computers in Human Behavior, 70, 178-190.

Hu, X., Griffin, M. A., \& Bertuleit, M. (2016). Modelling antecedents of safety compliance: Incorporating theory from the technological acceptance model. Safety Science, 87, 292-298.

Job, M. A., \& Ogalo, H. S. (2012). Micro learning as innovative process of knowledge strategy. International Journal of Scientific \& Technology Research, 1(11), 92-96.

Koh, J. H. L., Chai, C. S., \& Lim, W. Y. (2017). Teacher professional development for TPACK21CL: Effects on teacher ICT integration and student outcomes. Journal of Educational Computing Research, 55(2), 172-196.

Kurniawan, K. (2005). Panduan Penulisan Buku Ajar. Bandung: Universitas Pendidikan Indonesia. Li, X., Liu, J., Han, J., \& Zhang, Q. (2011). The architecture design of micro-learning platform based on cloud computing. Proceedings of the 2011 International Conference on Innovative Computing and Cloud Computing, 80-83. ACM.

Locatis, C., Gaines, C., Liu, W.-L., Gill, M., Carney, J., Foster, J., ... Woods, M. (2006). A blended training approach using videoconferencing for distance education. Journal of the Medical Library Association, 94(4), 464.

Lotrecchiano, G. R., McDonald, P. L., Lyons, L., Long, T., \& Zajicek-Farber, M. (2013). Blended learning: strengths, challenges, and lessons learned in an interprofessional training program. Maternal and Child Health Journal, 17(9), 1725-1734.

Mercurio, M., Torre, I., \& Torsani, S. (2011). Design of Adaptive Micro-Content in Second Language Acquisition. Journal of E-Learning and Knowledge Society, 7(3), 109-119.

Mintowati. (2003). Panduan Penulisan Buku Ajar. Jakarta: Depdikbud.

Mouzakis, C. (2008). Teachers' perceptions of the effectiveness of a blended learning approach for ICT teacher training. Journal of Technology and Teacher Education, 16(4), 461-482.

Nur, F. M. (2016). Pemanfaatan sumber belajar dalam pembelajaran sains kelas V SD pada pokok bahasan makhluk hidup dan proses kehidupan. JESBIO: Jurnal Edukasi Dan Sains Biologi, l(1).

Pamuk, S., Ergun, M., Cakir, R., Yilmaz, H. B., \& Ayas, C. (2015). Exploring relationships among TPACK components and development of the TPACK instrument. Education and Information Technologies, 20(2), 241-263.

Park, Yasung, \& Kim, Y. (2018). A design and Development of micro-Learning Content in eLearning System. International Journal on Advanced Science, Engineering and Information Technology, 8(1), 56-61.

Park, Yeonjeong. (2011). A pedagogical framework for mobile learning: Categorizing educational applications of mobile technologies into four types. International Review of Research in Open and Distance Learning. https://doi.org/10.3394/0380-1330(2006)32 
Rosdiana, H. (2007). Pengaruh Pemanfaatan Sumber Belajar Terhadap Hasil Belajar Akuntansi Pada Siswa Kelas XI Semester II SMA Negeri 2 Wonogiri. Universitas Negeri Semarang.

Saleh, M., \& Sultan, S. (2016). Pengembangan Bahan Ajar Bahasa Indonesia Berbasis Kurikulum 2013 yang Mengintegrasikan Nilai Karakter Bangsa di SMP. Jurnal Pendidikan Dan Pembelajaran (JPP). Retrieved from http://journal.um.ac.id/index.php/pendidikan-danpembelajaran/article/view/7733

Sánchez-Alonso, S., Sicilia, M.-A., García-Barriocanal, E., \& Armas, T. (2006). From microcontents to micro-learning objects-which semantics are required?(semantics for microlearning). Micromedia \& E-Learning, 2, 295-303.

Satrianawati. (2018). Media Dan Sumber Belajar. Yogyakarta: CV Budi Utama.

Stephansen, H. C., \& Couldry, N. (2014). Understanding micro-processes of community building and mutual learning on Twitter: a 'small data'approach. Information, Communication \& Society, 17(10), 1212-1227.

Sun, G., Cui, T., Chen, S., Guo, W., \& Shen, J. (2015). MLaaS: A cloud system for mobile micro learning in MOOC. 2015 IEEE International Conference on Mobile Services, 120-127. IEEE.

Surahman, E., \& R. (2014). Gerakan Revitalisasi Peduli Pangan Untuk Menciptakan Kemandirian Masyarakat Menuju Indonesia Sejahtera. Agrinova Himmpas IPB, 39-45. Bogor: Himmpas IPB.

Surahman, E. (2019). Integrated Mobile Learning System (IMOLES) sebagai Upaya Mewujudkan Masyarakat Pebelajar Unggul Era Digital. JINOTEP (Jurnal Inovasi Dan Teknologi Pembelajaran) Kajian Dan Riset Dalam Teknologi Pembelajaran, 5(2), 50-56.

Tang, M. R., Jufri, J., \& Sultan, S. (2016). Pengembangan Bahan Ajar Cerita Fiksi Berbasis Wacana Budaya di Sekolah Dasar. Jurnal Pendidikan Dan Pembelajaran .... Retrieved from http://journal.um.ac.id/index.php/pendidikan-dan-pembelajaran/article/view/7743

Wedi, A. (2017). Pendayagunaan Sumber Belajar Dalam Implementasi Strategi Penyampaian Pembelajaran Tematik. Edcomtech Jurnal Kajian Teknologi Pendidikan. Retrieved from http://journal2.um.ac.id/index.php/edcomtech/article/view/1791

Zaenal, A. (2009). Evaluasi pembelajaran. Bandung: PT Remaja Rosdakarya. 